\title{
Mistletoe Extract in the Palliation of End Stage Cancer
}

\author{
Sandeep Roy* \\ Practice of Medicine, Germany
}

Submission: September 12, 2017; Published: October 03, 2017

*Corresponding author: Sandeep Roy, Practice of Medicine, Specialist in Mistletoe Therapy for Cancer Management, AEMT, Germany, Email: dr_roysandeep@yahoo.com

\begin{abstract}
High incidence of death rate among cancer patients in addition to the mental depression and reduction in the Immune strength had laid an immediate urge towards the palliation therapy contrary to the regular cancer treatment. The objective of the work is using the mistletoe extract in cancer palliation. Randomized population of cancer victims is selected for the study wherein the administration of mistletoe extract ranging from $0.02 \mathrm{mg}$ to $20 \mathrm{mg}$ over a period of 6 months in an ascending dosage given subcutaneous. Pain, Anorexia, Insomnia, Weight loss, Low immunity, Weakness like symptoms were analysed after the palliation treatment. Improved levels were reported for all the symptoms. Cancer Palliation targeting the above symptoms was successful with the use of mistletoe extract. Palliation is the best method of treating the victims of end stage cancer. The study also proved the soothing action of mistletoe extract and its importance in the palliation of end stage cancer patients.
\end{abstract}

\section{Introduction}

In the end stage cancer patients where in the cure is an obligate failure necessitates the palliation approach which focuses on creating an easy and comfort life to the patient rather than treating them as an experimental model for the research [1]. Palliation approach would help in the quality improvement of the end stage life whose recovery cannot be expected. Various palliation therapies have been developed which can mentally support the well-being of the victim. Massage is also proved to be the better approach in some of the diseases. The current work is an approach where in the use of mistletoe extract in various concentrations has been used towards reaching the goal [2]. Several studies provide the beneficial effects of the mistletoe and its palliation effect. The present work aimed towards analysing the palliation of cancer symptoms like Pain, Anorexia and Insomnia etc. Whose treatment would bring back the Psychological strength and general immunity of the patient? The study is based on the use of a treatment methodology which emphasizes on maintaining the patients mental condition and peace by controlling or totally preventing the side effects. Apart from its pathogenic activity, the new scientific era has revealed its importance in the treatment of cancer this breakthrough in the history of cancer therapy. There are very few side effects which may be caused by the use of mistletoe extract [3-8]. The inherent nature of this extract can provide a soothing effect for the patients thereby maintaining a pleasant environment for the patient. Palliation therapy focuses on the psychological effect of the patient rather than the metabolic change.

\section{Biochemical importance of mistletoe extract}

Mistletoe extract in its purified and sterile form in various strength are administered subcutaneously to control the symptoms of cancer. The extract has several biochemical and metabolic effects which are directly responsible for controlling the adverse effects of cancer [9-12]. The extract is known to have immuno-modulation wherein it activates the Macrophages and phagocyte cells and induces apoptosis thereby controlling the cell number [13]. It is also known to cause dose dependent cytotoxicity thereby regulating the cell count in cancer condition. Animal experiments also proved that the extract is known for its inhibition of tumours and metastasis [14]. There are also first indications of inhibition of tumour angiogenesis.

\section{Materials and Methods}

\section{Collection of the patient volunteers}

The author being a medical doctor has good direct access for the patients. The patients diagnosed with the cancer and qualifying all the eligibility criteria were selected for the study. All the study population are from Rishikesh hospital and Research Centre, Nasik, Maharashtra, India. A written consent was undertaken from all the patients for the current study. A questionnaire was also attended by the study population to 
evaluate the other physiological and psychological changes after the treatment.

\section{Study population selection criteria}

83 individuals in their last i.e. $4^{\text {th }}$ stage of cancer who had already received the conventional treatment methodologies and exhibiting marked side effects were selected for the study. The major criteria considered while selecting is that the patients who have no chances of treatment and recovery so as to direct them towards good life rather than complete life. Patients who were still on their conventional treatment with no side effects were excluded from the study.

\section{Methodology}

All the study population were regularly monitored for the physical and Psychological changes during the entire regimen. The mistletoe extracts were used in the entire study. Subcutaneous injections of the extract were delivered every alternative day to all the 83 population in an ascending dosage. The concentration of the extract was started from $0.02 \mathrm{mg}$ and was gradually increased to a range of $0.2 \mathrm{mg}, 2 \mathrm{mg}$ and finally to a maximum range of $20 \mathrm{mg}$ for a period of 6 months ( 8 ampoules of each strength was used before escalating to the next strength). All the Physical and Psychological changes in the patients were recorded with at most care. Other physiological parameters like pain, insomnia, anorexia, weight loss, weakness and decreased immunity were also monitored and recorded at regular intervals.

\section{Results and Discussion}

Table 1: The biochemical and diagnostic parameters measured during the treatment regimen.

\begin{tabular}{|c|c|c|c|}
\hline Concentration of Mistletoe Extract & Effect on CBC & Effect on LFT And RFT & Effect on ESR \\
\hline $0.02 \mathrm{mg}$ & $\begin{array}{c}50 \text { showed improvement in the } \\
\text { values, } 19 \text { showed no effect, } 14 \\
\text { showed a very slight change in the } \\
\text { values }\end{array}$ & $\begin{array}{l}30 \text { showed the sign of } \\
\text { improvement } 27 \text { showed a good } \\
\text { change in the values, } 26 \text { showed } \\
\text { no measurable change }\end{array}$ & $\begin{array}{c}\text { Decreased ESR level was found } \\
\text { in } 72 \text { patients and } 11 \text { showed no } \\
\text { measurable change }\end{array}$ \\
\hline $0.2 \mathrm{mg}$ & $\begin{array}{l}64 \text { showed good improved values } \\
\text { of } \mathrm{CBC} \text { and } 6 \text { showed a slight } \\
\text { change in the values and } 13 \\
\text { showed no effect }\end{array}$ & $\begin{array}{l}26 \text { showed an improved } \\
\text { activity, } 43 \text { showed a very good } \\
\text { improvement and } 14 \text { has no effect }\end{array}$ & $\begin{array}{l}\text { ESR was decreased to a } \\
\text { greater extent and quality of } \\
\text { life improved in } 76 \text { among the } \\
\text { patients and } 7 \text { showed no effect }\end{array}$ \\
\hline $2.0 \mathrm{mg}$ & $\begin{array}{c}\text { A very good effect was observed } \\
\text { in all the } 64 \text { with } 19 \text { having no } \\
\text { measurable effect }\end{array}$ & $\begin{array}{l}\text { Very good recovery was seen in all } \\
\text { the } 64 \text { samples }\end{array}$ & $\begin{array}{l}\text { Perfect improvement in the } \\
\text { ESR rate among all } 73 \text { with } 10 \\
\text { having no change }\end{array}$ \\
\hline $20.0 \mathrm{mg}$ & $\begin{array}{c}\text { A drastic change in the CBC } \\
\text { which showed the cell elevations } \\
\text { nullified among } 64 \text { of the } \\
\text { individuals }\end{array}$ & $\begin{array}{l}\text { LFT and RFT were near to normal } \\
\text { in all the } 66 \text { samples with } 17 \\
\text { showing no betterment }\end{array}$ & $\begin{array}{l}\text { ESR improved drastically among } \\
\text { all } 76 \text { individuals }\end{array}$ \\
\hline
\end{tabular}


83 Random populations affected with cancer and suffering in their 4th stage are chosen. All the patients had marked side effects due to the regular treatment methodologies. The study aimed to provide these patients a better quality of the remaining life rather than prolonging their existing life span. All the 83 individuals were administered with the mistletoe extract from a dosage range of $0.02 \mathrm{mg}$ to $20 \mathrm{mg}$ in an ascending order for a period of 6 months. All the results were recorded in terms of parameters like CBC, CRP, LFT, RFT etc. Additionally the symptoms like pain, anorexia, and insomnia etc were also analysed in regular intervals. Table 1 symptoms like pain and anorexia were nearly eliminated among the patients; however the rate of improvement varied among the individuals. Insomnia was greatly affected as more than 70 individuals reported a good sleep time during and after the treatment regimen. The physical stamina also showed an improved status in addition to the mental strength. The improvement was at a great extent that the use of analgesics for pain relief was totally stopped after the therapy in some cases. There was a great improvement in the body mass and a reduced tumour cell weight. Cell Apoptosis rate was found to be increased due to the administration of mistletoe extract. The study was successful for 64 individuals among the total 83 considered.

\section{Conclusion}

The current work was targeted to the end stage $4^{\text {th }}$ degree cancer patients who have no chances of recovery and had high and marked side effects due to the regular cancer treatment methodologies. The study aimed to provide a better quality of life to the end stage patients rather than prolonging their life mechanically. The major point of concern in treating these patients is their Psychological condition and mental peace. Palliation of caner is the best option for the doctors at this stage of life. The study uses Mistletoe Extract in reaching its goal. The extract was subcutaneously administered for a study population of 83 in an ascending order starting from $0.02 \mathrm{mg}$ to $20 \mathrm{mg}$ for a period of 6 months.

All the parameters like CBC, LFT, RFT, ESR, CRP etc. were recorded at regular intervals. Apart from the biochemical parameters, physiological symptoms were also taken care of. The most treating symptoms like Weight loss, Weakness, Decreased Immune strength, Pain, Anorexia, Insomnia were focussed during the entire treatment protocol. The results were very much satisfactory for a population of 64 to a total of 83. All the biochemical parameters mentioned indicated an improved life quality during and after the treatment. The CBC was decreased due to an increased level of apoptosis, Insomnia was nearly eliminated and pain was completely cured to such an extent that the use of analgesics was completely stopped in some cases. The measurement of tumour markers showed a decreased values and improved body weight was reported. To conclude the treatment regimen using mistletoe in the palliation of end stage cancer was highly successful at a rate of $77 \%$ in not only improving the biochemical and metabolic status of the patient but also in bringing back the psychological status of the patient. The above study showed a success rate of $77 \%$ while the others still had adverse reaction which was out of control towards this particular treatment protocol.

\section{References}

1. (2016) Mistletoe Extracts-Health Professional Version (PDQ ${ }^{\circledR}$ ). National Cancer Institute.

2. Horneber MA, Bueschel G, Huber R (2008) Mistletoe therapy in oncology. Cochrane Database Syst Rev 16(2): CD003297.

3. Understanding Your Lab Test Results, American Cancer Society.

4. Cancer Research UK, what is palliative treatment and when should it be, let's beat cancer sooner.

5. Raikar GV, Matthew MM, Ress A (1996) Cost-effective analysis of surgical palliation versus endoscopic stenting in the management of unresectable pancreatic cancer. Ann Surg Oncol 3(5): 470-475.

6. Tey J, Back MF, Shakespeare TP, Mukherjee RK, Lu JJ, et al. (2007) The role of palliative radiation therapy in symptomatic locally advanced gastric cancer. Int J Radiat Oncol Biol Phys 67(2): 385-388.

7. Roy S (2014) Comparative evaluation between Quality of life (Qol), adverse events and survival analysis of mistletoe extract for the treatment of solid tumors. Asian J Pharm Clin Res 7(2): 10-14.

8. Moliterni A, Tarenzi E, Capri G (1997) Pilot study of primary chemotherapy with doxorubicin plus paclitaxel in women with locally advanced or operable breast cancer. Semin Oncol 24(5 Suppl 17): 1014.

9. Kim KC, Yook JH, Eisenbraun J, Kim BS, Huber R, et al. (2014) Quality of life, immunomodulation and safety of adjuvant mistletoe treatment in patients with gastric carcinoma -a randomized, Sandeep Roy. Comparative evaluation between Quality of life (Qol), adverse events and survival analysis of mistletoe extract for the treatment of solid tumors. Asian J Pharm Clin Res 7(2): 10-14.

10. Tong D, Gillick L, Hendrickson FR (1982) The palliation of symptomatic osseous metastases final results of the study by the radiation therapy oncology group. Cancer 50(5): 893-899.

11. Serafini AN, Houston SJ, Resche I, Quick DP (1998) Palliation of pain associated with metastatic bone cancer using samarium-153 lexidronam: a double-blind placebo-controlled clinical trial. J Clin Oncol 16(4): 1574-1581.

12. Karoui M, Charachon A (2007) Stents for palliation of obstructive metastatic colon cancer impact on management and chemotherapy administration. Arch Surg 142(7): 619-623.

13. Jayasinghe UW, Taylor R, Boyages J (2005) Is age at diagnosis an independent prognostic factor for survival following breast cancer? ANZ J Surg 75(9): 762-767.

14. Molassiotis A, Scott JA, Kearney N, Pud D, Magri M, et al. (2006) Complementary and alternative medicine use in breast cancer patients in Europe. Support Care Cancer 14(3): 260-267. 
This work is licensed under Creative Commons Attribution 4.0 Licens DOI: 10.19080/JTMP.2017.02.555584
Your next submission with Juniper Publishers will reach you the below assets

- Quality Editorial service

- Swift Peer Review

- Reprints availability

- E-prints Service

- Manuscript Podcast for convenient understanding

- Global attainment for your research

- Manuscript accessibility in different formats

( Pdf, E-pub, Full Text, Audio)

- Unceasing customer service

Track the below URL for one-step submission https://juniperpublishers.com/online-submission.php 